\title{
Calcareous nannofossil bioevents and microtektite stratigraphy in the Western Philippine Sea during the Quaternary
}

\author{
SUN HanJie ${ }^{1,2}$, LI TieGang $^{1 *}$, SUN RongTao $^{3}$, YU XinKe $^{1}$, CHANG FengMing $^{1} \&$ \\ TANG Zheng ${ }^{1,4}$ \\ ${ }^{1}$ Key Laboratory of Marine Geology and Environment, Institute of Oceanology, Chinese Academy of Sciences, Qingdao 266071, China; \\ ${ }^{2}$ Graduate University of the Chinese Academy of Sciences, Beijing 100049, China; \\ ${ }^{3}$ School of Resource \& Environment Engineering, Shandong University of Technology, Zibo 255049, China; \\ ${ }^{4}$ China Geological Survey, Qingdao Institute of Marine Geology, Qingdao 266007, China
}

Received January 21, 2011; accepted May 24, 2011

Two sediment cores, MD06-3050 and MD06-3047, were analyzed to study the Quaternary calcareous nannofossil and microtektite records. We dated bioevents and the microtektite impact event by calibrating with oxygen isotope stratigraphy. Seven calcareous nannofossil bioevents were identified over the past $2.36 \mathrm{Ma}$ including the last appearance of data for Discoaster brouweri, Calcidiscus macintyrei, large Gephyrocapsa and Pseudoemiliania lacunosa, the first appearance of data for large Gephyrocapsa and Emiliania huxleyi, and the abrupt increase in the abundance of Gephyrocapsa caribbeanica. In addition, we fortunately observed that Australasian microtektites were distributed in core MD06-3050 from 1340 to $1374 \mathrm{~cm}$.

Western Philippine Sea, Quaternary Period, calcareous nannofossil biostratigraphy, oxygen isotope stratigraphy, Australasian microtektites

Citation: Sun H J, Li T G, Sun R T, et al. Calcareous nannofossil bioevents and microtektite stratigraphy in the Western Philippine Sea during the Quaternary. Chinese Sci Bull, 2011, 56: 2732-2738, doi: 10.1007/s11434-011-4603-z

Calcareous nannofossils are sensitive indicators for paleoenvironments and important tools for chronology [1-4] because of their small size (usually less than $30 \mu \mathrm{m}$ ), quick evolution, wide distribution, richness in sediments, and simple sample preparation. In recent decades, calcareous nannofossil biostratigraphy has improved and developed. Calcareous nannofossil biostratigraphy has been combined with magnetism stratigraphy, isotope stratigraphy, lithostratigraphy and volcanostratigraphy in comparing stratigraphy and the environment on a global scale, providing a basis for paleoceanography. Increasing numbers of researchers, such as Thierstein et al., Gartner, Matsuoka and Okada, Giraudeau and Pujos, Wei, Raffi et al., Weaver and Thomson, Wells and Okada, Hine and Weaver, and Bollmann et al., have placed an emphasis on improving calcareous nannofossil biostratigraphy [5-14]. They have established de-

*Corresponding author (email: tgli@qdio.ac.cn) finitively the timing of calcareous nannofossil bioevents in different periods during the Quaternary Period. However, most of their studies focus on mid-latitude and equatorial regions. As one of the largest marginal seas in the Western Pacific Ocean, and also the source region of the Kuroshio, the Western Philippine Sea has an important role in global climate changes and ocean evolution. Unfortunately, there have been few works on calcareous nannofossil biostratigraphy in this area. Wei et al. [15] identified several calcareous nannofossil bioevents in the MD97-2143 core taken from the Benham Rise, but did not record the oxygen isotope stratigraphy. Therefore, they were unable to date each bioevent. Further study is necessary to investigate the evolutionary history of calcareous nannofossils and provide valuable chronological data for this area.

Microtektites are natural glass rocks smaller than $1 \mathrm{~mm}$ that were formed by the melting of terrestrial surface deposits/rocks during the impact of an extraterrestrial body [16]. 
Since mid-Pleistocene Australasian microtektites were first detected in cores taken from the Indian Ocean, they have been found in cores of the Western Pacific marginal seas, such as the Western Philippine Sea and the South China Sea [17-19]. Because of their wide distribution over oceans and continents, the occurrence of Australasian microtektites can be used as a reliable age point in stratigraphy. The event took place close to the boundary of the Matuyama-Brunhes geomagnetic reversal. A large number of microtektites were observed at the ODP292 site [20] and in the MD97-2143 core [19]. The average sedimentation rate for the core MD97-2143 was obtained according to two tie points: the core top at $0 \mathrm{ka}$ and the Brunhes-Matuyama boundary at $778 \mathrm{ka}$ [21]. The age of the impact event was then calculated in a straightforward manner.

The Marco Polo 2 cruise offered appropriate materialsthe sediment cores of MD06-3050 and MD06-3047-to study the evolution of calcareous nannofossil assemblages in the Western Philippine Sea during the Quaternary Period. Good oxygen isotopic records were achieved for the two cores, and the bottom age of the MD06-3050 core was determined as $2.36 \mathrm{Ma}$. The present study focused on the identification and calibration of important calcareous nannofossil bioevents to improve the stratigraphic framework for the Western Pacific Ocean in paleoceanographic studies. Additionally, microtektites were fortunately discovered in some layers of the MD06-3050 core. On the basis of the good oxygen isotope stratigraphy, we can further improve the accuracy of the date of the impact event.

\section{Materials and methods}

\subsection{Core location and description}

Two cores were retrieved from the Western Philippine Sea: one was the Calypso core MD06-3050 (15 ${ }^{\circ} 57.0943^{\prime} \mathrm{N}$, $124^{\circ} 46.7747^{\prime} \mathrm{E}$, length $31.75 \mathrm{~m}$, depth $2967 \mathrm{~m}$ ) and the other was the CASQ core MD06-3047 $\left(17^{\circ} 00.44^{\prime} \mathrm{N}, 124^{\circ} 47.3^{\prime} \mathrm{E}\right.$, $8.9 \mathrm{~m}$ length, $2510 \mathrm{~m}$ depth). Both cores were taken from the Benham Rise, east off Luzon Island (Figure 1).

The two cores are yellowish silty mud with obvious black volcanic ash layers and rich in nannofossil-foraminifera ooze. They are situated above the lysocline $(3400 \mathrm{~m})$ in the study area [22], allowing for good preservation of carbonate. The MD06-3047 core contained continuous sediments with no obvious gap or abrupt interruption. Some layers were absent in MD06-3050, such as the 0-6 cm layer of the core top, the middle-upper section at 986-1002 cm, and the mid-section at $1672-1684 \mathrm{~cm}$. However, other sections of the MD06-3050 core were continuous. According to oxygen isotope stratigraphy, both cores were found to have a low sedimentation rate, although the rate was slightly higher in the MD06-3050 core than in the MD06-3047 core. We analyzed for the entire length of the MD06-3047 core and the upper $2800 \mathrm{~cm}$ of the MD06-3050 core.

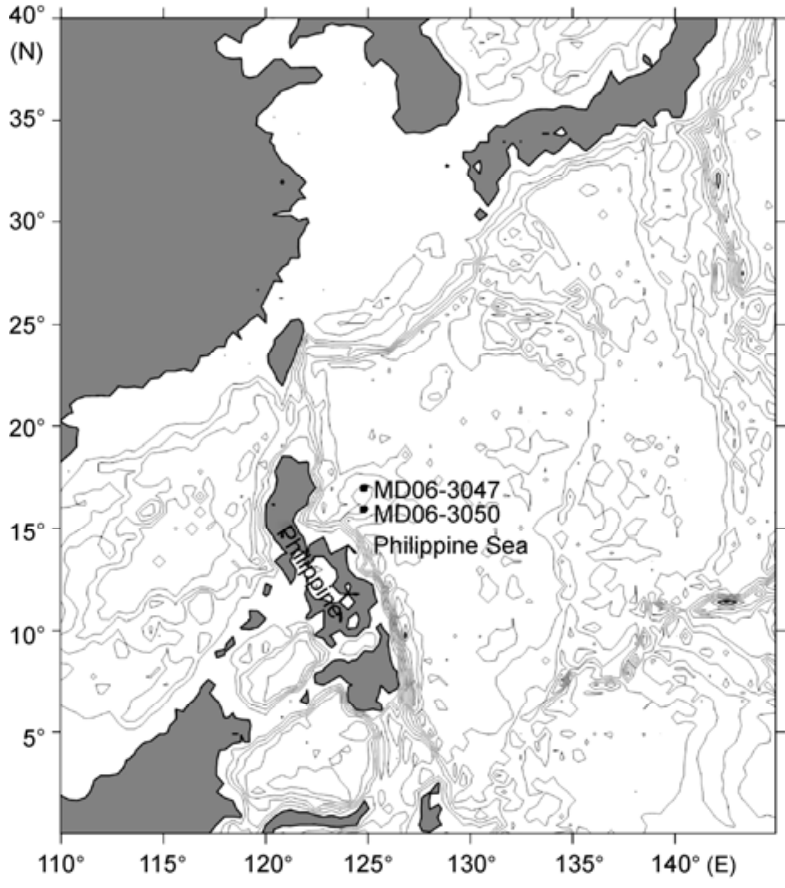

Figure 1 Locations of study sites in the Western Philippine Sea.

\subsection{Calcareous nannofossil preparation technique and estimation of abundance}

Smear slides were made directly from unprocessed samples and systematically examined with a Leica (DM RX) crosspolarized light microscope at a magnification of $1000 \times$. For each sample, semiquantitative data were collected by counting at least 500 coccolith species, corresponding to more than 15 view fields. Given a 95\% confidence level, such a sample size assured the presence of a taxon whose relative abundance was at least $1 \%$ of the total population $[23,24]$. According to the relative abundances of different index species in each sample, we divided the counting results into four groups according to the literature [25]. Dominant species accounted for at least $50 \%$ of the total assemblage, abundant species for $10 \%-50 \%$, common species for $1 \%-10 \%$, species few-in-number for $0.1 \%-1 \%$, and rare species for less than $0.1 \%$. The dominant species in the study area was Florisphaera profunda, with relative abundance above $50 \%$. Its abundance was because of a deep thermocline/nutricline in the margin of the Western Pacific Warm Pool, and was in agreement with conclusions drawn in previous studies on the Western Pacific [26,27].

Most of the biostratigraphy index species in the analyzed cores were classified as common according to the standard mentioned above, with other species being classified as few-in-number. In the case of the layers with marker species in the few-in-number group, such as large Gephyrocapsa (>5.5 $\mu \mathrm{m})$, Calcidiscus macintyrei, and Discoaster brouweri, we excluded $F$. profunda from the total number larger than $4 \mu \mathrm{m}$. Analyzed samples were collected at 4-10 cm intervals.

The two cores had little etching and overgrowth because 
of good preservation. However, reworked species, such as Pliocene species, were noted in some samples of the MD063050 core. The observation implies that there was lateral removal in sediments, which should be noted and identified.

\subsection{Microtektite counting method}

Samples of $2 \mathrm{~cm}$ thickness were taken every $2 \mathrm{~cm}$ continuously through the microtektite layers. About $5 \mathrm{~g}$ of dry samples was taken and wet-sieved through a mesh with 63 $\mu \mathrm{m}$ pores. The aliquots larger than $63 \mu \mathrm{m}$ were dried in an oven at $50^{\circ} \mathrm{C}$. Afterward, we handpicked all microtektites larger than $150 \mu \mathrm{m}$ using a binocular microscope. The microtektite number in each layer was counted to calculate the absolute abundance in units of number per gram.

\subsection{Oxygen isotope stratigraphy}

Oxygen isotope data obtained from foraminiferal tests carried out for MD06-3050 and MD06-3047 were recorded by the GV IsoPrime mass spectrometer at the Key Laboratory of Marine Geology and Environment, Institute of Oceanography, Chinese Academy of Sciences, Qingdao, China. Around 20-30 specimens of Globigerinoides ruber, a surface-dwelling species, were picked from the 150-350 $\mu \mathrm{m}$ fraction. The standard deviation is $0.08 \%$ for $\delta^{18} \mathrm{O}$. Conversion to the international Peedee Belemnite (PDB) scale was performed using NBS18 standard. Both cores were sampled in $2 \mathrm{~cm}$ intervals with some absence for analysis of planktonic foraminiferal oxygen isotopes.

The two oxygen isotope curves show obvious glacial/ interglacial cycles. The chronostratigraphy was based on correlation of our $\delta^{18} \mathrm{O}$ curves to the LR04 stack record [28], combining one $\mathrm{AMS}^{14} \mathrm{C}$ age for MD06-3050. The one $\mathrm{AMS}^{14} \mathrm{C}$ datum was determined for monospecific planktonic foraminiferal G. ruber in the $28-30 \mathrm{~cm}$ layer and recorded at the National Ocean Sciences Accelerator Mass Spectrometry Facility, Woods Hole Oceanographic Institution, Massachusetts, USA. We converted the $\mathrm{AMS}^{14} \mathrm{C}$ age into a calendar age of 10300 a using the online program CALIB6.0html [29]. We established the oxygen isotope stratigraphy for the MD06-3050 core over the last 2.36 Ma (Figure 2(b)) and for the MD06-3047 core over the last 690 ka (Figure 2(c)).

\section{Results and discussion}

\subsection{Calcareous nannofossil bioevents during the past $2.36 \mathrm{Ma}$}

(1) First appearance of Emiliania huxleyi. Emiliania huxleyi is a ubiquitous species, widely distributed in the modern oceans [30]. Because of its tiny size, usually less than $4 \mu \mathrm{m}$, it is possible to confuse it with other small species. Therefore, scanning electron microscopy (SEM) was employed to confirm identification and obtain an accurate biohorizon; the total number of specimens exceeded 500 .

The first appearance of datum (FAD) of E. huxleyi was observed at 516-518 cm in the MD06-3050 core, with abundance of $0.2 \%$ (Figure 2(f)). Oxygen isotope stratigraphy indicates this bioevent occurred $262.2 \pm 1 \mathrm{ka}$ ago. In the case of the MD06-3047 core, the FAD of E. huxleyi was observed in the $336-338 \mathrm{~cm}$ layer, with abundance of $0.33 \%$ (Figure 2(d)), corresponding to an age of $264 \pm 1.5 \mathrm{ka}$. Considering the different sedimentation rates for the two cores, slight time discrepancies are reasonable.

The FAD of E. huxleyi has been generally recorded as $268 \mathrm{ka}$ in the Atlantic, Pacific and Southern oceans and thus belonging to Marine Isotope Stage (MIS) 8 [5,31]. The biohorizon represents the most recent biostratigraphic event during the Quaternary. The characteristics in the Western Philippine Sea further attest that the FAD of E. huxleyi is a globally synchronous bioevent.

(2) Last appearance of Pseudoemiliania lacunosa. In the MD06-3050 core, the abundance of Pseudoemiliania lacunosa was $0.43 \%$ in the 960-962 cm layer, corresponding to an oxygen isotope age of $458 \mathrm{ka}$. P. lacunosa then disappeared in the next several layers. However, this species was again present at 940-942 $\mathrm{cm}$ (about $450 \mathrm{ka}$ ), with abundance of $1.39 \%$, before becoming more scarce in the following layers. The final disappearance of $P$. lacunosa was in the 924-926 cm layer (443 ka) (Figure 2(f)).

A similar distribution was reconstructed for P. lacunosa in core MD06-3047. In this core, P. lacunosa had abundance of $0.17 \%$ in the $602-604 \mathrm{~cm}$ layer, at an age estimate of $456 \mathrm{ka}$, and then disappeared in the next several layers (Figure 2(d)). Again, this species was present at 574-576 cm (about $439 \mathrm{ka}$ ) and 570-572 cm (about $433 \mathrm{ka}$ ) with abundance less than $1 \%$, and was not present in any higher layer.

The two abundance change curves of $P$. lacunosa in the MD06-3047 core and MD06-3050 core were compared. They both showed zero abundance at an age estimate of 458 ka or so, which was in agreement with data for other regions [5,25]. For example, the last appearance of datum (LAD) of $P$. lacunosa was identified in MIS12 by Thierstein et al. However, we note that the cores we studied had unique characteristics. After disappearing at an age of about $458 \mathrm{ka}$, $P$. lacunosa reappeared. The only difference between the MD06-3047 core and MD06-3050 core was that the LAD of $P$. lacunosa for the former was slightly later than that for the latter, possibly because of their different locations and sedimentation rates. The specimens reappearing after the first extinction is a phenomenon unique to the Western Philippine Sea and may be due to slight resedimentation. Nevertheless, we still consider $458 \mathrm{ka}$ as the bioevent time in view of the consistent timing of the first extinction.

(3) Abrupt increase in the abundance of Gephyrocapsa caribbeanica. We obtained the abundance curve of $G$. caribbeanica in the core of MD06-3047. The abundance of this species abruptly increased from the $638-640 \mathrm{~cm}$ layer to the 
(a)

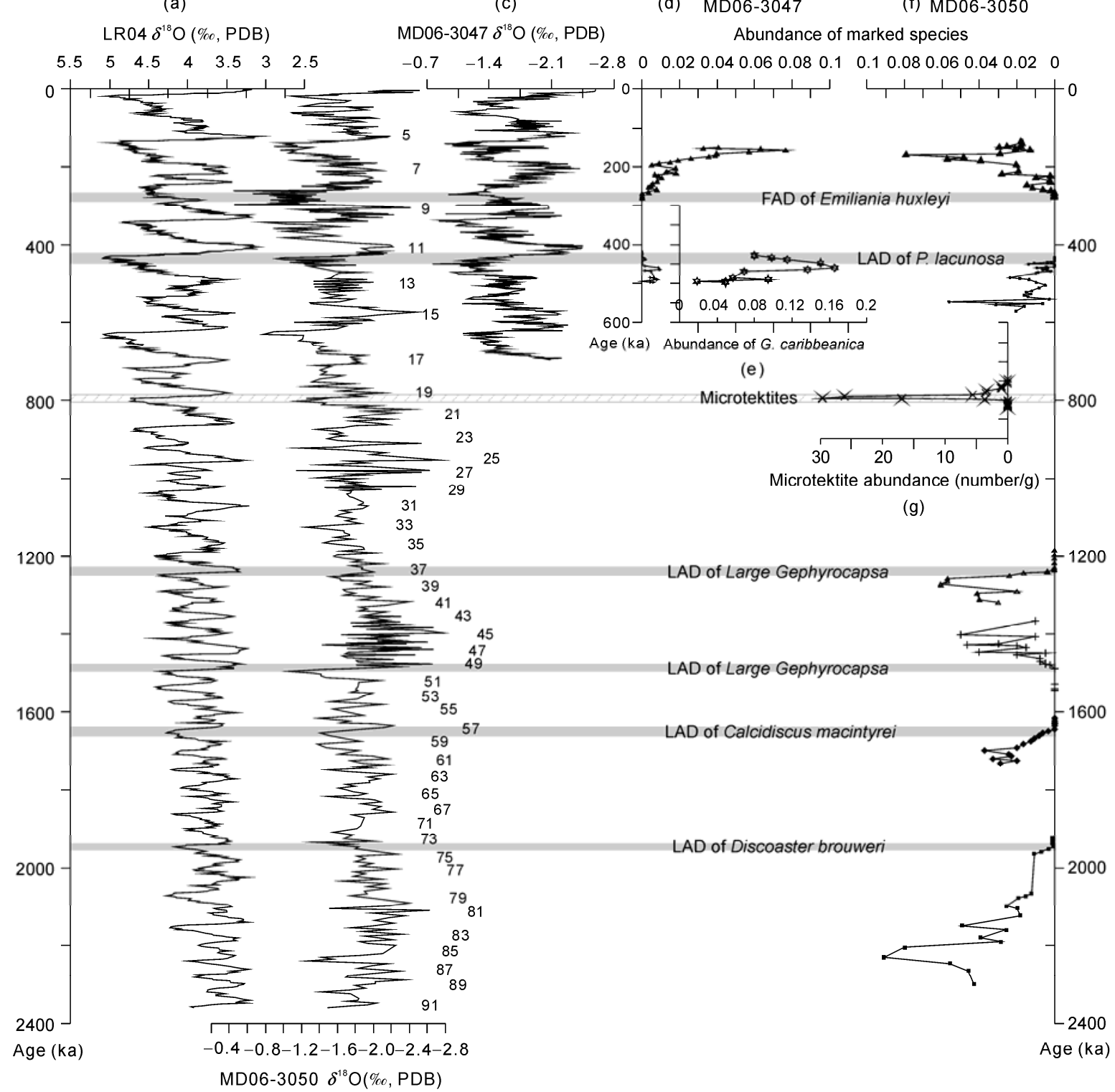

(b)

Figure 2 Records of oxygen isotope curves, microtektite abundance and calcareous nannofossil bioevents for the MD06-3050 core and MD06-3047 core. (a) Benthic foraminiferal oxygen isotope stratigraphy of LR04 [28] is shown for comparison. (b) Measured $\delta^{18} \mathrm{O}$ stratigraphy for planktonic foraminifera $G$. ruber in the MD06-3050 core. Numbers to the right of the $\delta^{18} \mathrm{O}$ curve indicate interglacial intervals. (c) Measured $\delta^{18} \mathrm{O}$ stratigraphy for planktonic foraminifera G. ruber in the MD06-3047 core. (d) Abundance curves of coccolith species E. huxleyi (top) and P. lacunosa (bottom) in the MD06-3047 core. (e) Curve of the abrupt increase in the abundance of coccolith species G. caribbeanica in the MD06-3047 core. (f) Abundance curves for all calcareous nannofossil marker species in the MD06-3050 core. Gray-shaded bars show the bioevents corresponding to oxygen isotope intervals; from top down, the FAD of E. huxleyi, LAD of P. lacunosa, LAD of large Gephyrocapsa, FAD of large Gephyrocapsa, LAD of C. macintyrei, and LAD of D. brouweri. (g) Variation in microtektite abundance in the MD06-3050 core. The transverse represents the abundance in units of number per gram. The maximum abundance is shown by the hatch-patterned strip. The $y$-axes in all figures indicate age with the same time scale.

646-648 cm layer (Figure 2(e)), from $1.9 \%$ to a high value of $9.5 \%$ that was then maintained. Among all studied layers, the highest abundance was $16.6 \%$, corresponding to an oxygen isotope age of $489 \pm 1 \mathrm{ka}$ in MIS13. This is consistent with findings for other areas of the global ocean $[7,14,25,32]$. The results suggest that the bloom of G. caribbeanica was a synchronous event in the global ocean.

(4) Last appearance (top) of large Gephyrocapsa (hereafter $\mathrm{tlG}$ ). Following the informal morphometric subdivi- sion established by Raffi et al. [10], a biohorizon was defined by the appearance in the stratigraphic record of specimens of the genus Gephyrocapsa with size larger than 5.5 $\mu \mathrm{m}$. The taxonomy is simple and practical and thus adopted widely in calcareous nannofossil biochronology. tlG was clearly defined and easily recognized because of the large size and abrupt decrease in abundance before extinction. The biohorizon was considered a globally synchronous event that occurred in MIS37, with an age estimate of 1.24 
Ma determined from cores distributed in the Pacific, Atlantic, Southern oceans and the Mediterranean Sea [7,9,10,31,33].

In the MD06-3050 core, tlG was identified in the 1836$1838 \mathrm{~cm}$ layer with abundance of $0.38 \%$ (Figure 2(f)). Correlating with the oxygen isotope stratigraphy, the age was fixed at $1.24 \pm 0.002 \mathrm{Ma}$, corresponding to mid-MIS37 and in agreement with previous evaluations. Additionally, the species abruptly decreased in abundance before disappearing in the MD06-3050 core, which resembles characteristic changes in other regions. Results presented here further confirm the previous findings.

(5) First appearance (base) of large Gephyrocapsa (hereafter blG). The FAD of large Gephyrocapsa was considered to be a diachronous event. Raffi et al. [10] defined it as slightly diachronous at sites in the Atlantic and Pacific oceans, occurring at the MIS49/48 transition, with an age estimate of 1.48 Ma. Differing with Raffi, Wei [9] found that blG occurred between MIS47 and MIS51, with obvious diachronicity at different locations. After further investigation, Raffi et al. [33] remeasured the abundance of this specimen at site ODP607 to emend the previous results, and considered that blG occurred at the MIS55/54 transition, with an age of $1.585 \pm 0.006 \mathrm{Ma}$. This value is similar to results obtained for the North Atlantic Ocean site ODP1063 and northeastern Indian Ocean site ODP758, where blG was determined to be within MIS55/54 and MIS54. Lourens et al. [34] analyzed high-resolution samples and located blG in MIS55 in the Mediterranean Sea. This age was about $130 \mathrm{ka}$ older than records for the open ocean. Similarly, the older age was found for other cores distributed in the Mediterranean Sea in the work of Raffi [33]. In addition, the biohorizon was dated at about $1.591 \pm 0.001 \mathrm{Ma}$ at the site ODP926 of the equatorial Atlantic [33], which was close to the record for the Mediterranean Sea [35] but older than the records for most ocean regions (about $1.48 \mathrm{Ma}$ ).

The FAD of large Gephyrocapsa $(>5.5 \mu \mathrm{m})$ was in the 2132-2134 cm layer in the MD06-3050 core, with abundance of $1 \%$, corresponding to the oxygen isotope age of $1.476 \pm 0.002 \mathrm{Ma}$ and the beginning of MIS49, rather close to the boundary of MIS49/MIS48. The result was close to that of Raffi et al. [10], which suggests that the specimen was more recent in the Western Philippine Sea than in most other ocean areas.

(6) Last appearance (top) of Calcidiscus macintyrei (hereafter tCm). Gartner [6] first put forward the idea that $C$. macintyrei disappeared in the early Pleistocene. Raffi et al. [10] and Wei [9] then attested that $\mathrm{tCm}$ was a diachronous bioevent, although Wei considered the bioevent synchronous at least in the area of equatorial ocean, in MIS 55, with an age estimate of 1.6 Ma or so. Raffi et al. [33] re-evaluated cores distributed in the global ocean, and indicated that the distribution of $C$. macintyre $i$ was affected by regional environmental conditions. They located tCm at the MIS56/55 transition, in agreement with previous evaluations at low latitude, such as at the equatorial ODP926 site (astronomi- cal age of $1.602 \pm 0.003 \mathrm{Ma}$ ) and Indian Ocean site ODP758. A new calibration of $\mathrm{tCm}$ in the mid-latitude Atlantic by Flores and Marino [25], at the MIS58/57 transition, disagrees with previous statements, which may be explained by considering the ecological factors controlling the distribution of this species. It is certain, however, that this species was present after the extinction of $D$. brouweri and before the appearance of large Gephyrocapsa $[6,9,10,36]$.

In the core MD06-3050, C. macintyrei was ascribed to the common group and was well preserved. In addition, this species was large in size-larger than $10 \mu \mathrm{m}$-and thus easy to identify via polarized light microscopy. As seen from Figure 2(f), the maximum abundance of about $4 \%$ was observed in the 2300-2302 cm layer, and the species decreased in abundance quickly in the following layers. The LAD of $C$. macintyrei was at $2272-2274 \mathrm{~cm}$, with abundance of $0.32 \%$, corresponding to an oxygen isotope age of $1.650 \pm 0.003 \mathrm{Ma}$ and MIS 55. This result is close to the disappearance time of $C$. macintyrei in the mid-latitude Atlantic Ocean, at the MIS58/57 transition, which was earlier than that determined in previous research of low-latitude ocean areas. We calculated that the sedimentation rate was about $1.25 \mathrm{ka} / \mathrm{cm}$ in the studied interval, which was lower than those of other sections of the core. Notably, low resolution may affect identification of this bioevent.

(7) LAD of Discoaster brouweri. Since Ericson et al. [37] first identified the LAD of $D$. brouweri, this bioevent has been generally used in low and mid-latitude zonation $[9,10$, 38]. Investigating sites distributed in four oceans, from a high latitude of $56^{\circ} \mathrm{N}$ to a low latitude of $2^{\circ} \mathrm{S}$ (ODP552, ODP607, ODP659, ODP662, ODP677, ODP709), Chapman et al. [39] confirmed that the extinction of D. brouweri occurred slightly above the base of the Olduvai Subchron (about 1.95 Ma). In addition, Fornaciari [40] studied sites in the low-latitude section of the California Current, and showed that the bioevent was reliable and basically in agreement with the events observed in previous works. However, it is noteworthy that sites distributed in the lowlatitude section of the California Current showed earlier extinction of $D$. brouweri [41], which agrees with results obtained for sites in the vicinity obtained by Fornaciari [40]. Although there was slight diachronicity in the mid-latitude California Current, the LAD of D. brouweri was completely within MIS76. The earlier extinction may have possibly been induced by cool waters and intense upwelling, which characterize the extreme regional environmental conditions.

The MD06-3050 core was located in the low-latitude Pacific Ocean, where $D$. brouweri was distributed extensively and lasted a long time, with relative high abundance in the older stratum. D. brouweri had low abundance in many layers before its extinction. We took the layer with abundance less than $0.5 \%$ for the LAD; this was the $2488-2490 \mathrm{~cm}$ layer with abundance of $0.3 \%$ (Figure 2(f)). According to oxygen isotope stratigraphy, the $2488-2490 \mathrm{~cm}$ layer was located in the middle of MIS74, having an age of $1.953 \pm$ 
$0.0025 \mathrm{Ma}$. The data presented here indicate that the extinction of $D$. brouweri in the Western Philippine Sea was synchronous with that in other low-latitude regions.

\subsection{Dated mid-Pleistocene microtektites in the Western Philippine Sea}

In the MD06-3050 core, a total of 354 microtektites, including fragments, were picked out and observed under a microscope. The color of microtektites varied from dark brownish to yellowish, and the microtektites appeared to have transparent and semitransparent rough glassiness. Microtektites had a variety of shapes. Most were spherical, elongated, droplets or irregular fragments. The microtektites were distributed at depths from 1340 to $1374 \mathrm{~cm}$, corresponding to oxygen isotope ages from 763.5 to $798 \mathrm{ka}$ and lay at the MIS20/MIS19 transition. The concentration of microtektites was a maximum in the $1364-1366 \mathrm{~cm}$ layer, about 30 per gram, corresponding to an age of $794 \mathrm{ka}$. The secondary abundance of microtektites was in the 1360-1362 $\mathrm{cm}$ layer, 26 per gram or so, corresponding to an age of $789.7 \mathrm{ka}$. The 1368-1370 $\mathrm{cm}$ layer had abundance of $\sim 19$ microtektites per gram. Few microtektites were scattered in other layers, numbering less than 6 per gram (Figure 2(g)).

Although we did not know the elemental geochemistry of these microtektites, according to their color, shape, fragmentation, age range from 763.5 to $798 \mathrm{ka}$ and comparison with other research results $[18,19]$, we inferred that they were produced by the impact of an extraterrestrial body in the Australasian strewn field [16,18,19,42-44]. Generally, the impact event is considered to have occurred during the period 730-800 ka. It is worth noting that some bioturbation may affect the original stratigraphic position of the microtektites in deep-sea sediment cores. Therefore, the layer with the highest concentration was treated as the original location. Fortunately, an abrupt increase and sharp decrease in the abundance curve of microtektites shows that the MD06-3050 core was little affected by bioturbation. The highest concentration of microtektites was within 1360$1366 \mathrm{~cm}$, giving an impact event with an age of $792 \pm 2 \mathrm{ka}$, near the boundary of MIS20/19.

The estimated age of the impact event in the MD06-3050 core was close to the time of this event as inferred from magnetostratigraphy and oxygen isotope stratigraphy in other regions $[18,19,45,46]$; it was about 12 ka earlier than the Matuyama-Brunhes boundary [21]. The correlation further supports the notion that the age corresponding to maximum abundance of microtektites can be considered a reliable age control point in the Indian and Pacific oceans.

\section{Conclusions}

Seven Quaternary calcareous nannofossil bioevents were detected in two cores taken from the Benham Rise in the
Western Philippine Sea on the basis of the abundance of coccolith marker species. According to the adopted age model, correlations between events and oxygen isotope stages were also proposed. We acquired the age of each bioevent as follows. The FAD of E. huxleyi had an age of 262-264 ka and was within MIS8; the LAD of P. lacunosa had an age of $458 \mathrm{ka}$ or so and was within MIS12; there was an abrupt increase in the abundance of $G$. caribbeanica in MIS13; the LAD of large Gephyrocapsa had an age of 1.24 $\pm 0.002 \mathrm{Ma}$; the FAD of large Gephyrocapsa had an age of $1.476 \pm 0.002 \mathrm{Ma}$; the LAD of $C$. macintyrei had an age of $1.650 \pm 0.003 \mathrm{Ma}$; and the LAD of $D$. brouweri had an age of $1.953 \pm 0.0025 \mathrm{Ma}$. Some of these bioevents were globally synchronous, whereas some had regional characteristics. In addition, a large number of Australasian microtektites were picked out from the MD06-3050 core. Correlating with the oxygen isotope stratigraphy, we located the formation time of microtektites at the MIS20/MIS19 transition. Calcareous nannofossil bioevents and microtektite stratigraphy of the MD06-3050 core provided a reliable chronological basis for paleoenvironment reconstruction in the Western Philippine Sea during the Quaternary Period.

We would like to thank the scientific party and crew of the Marion Dufresne for coring in the western Philippine Sea on the Marco Polo 2 cruise. We are sincerely grateful to the reviewers and the editor for their valuable comments and suggestions. This work was supported by the Pilot Project of the National Knowledge Innovation Program of the Chinese Academy of Sciences (KZCX2-YW-221), the National Natural Science Foundation of China (40906030, 40976026 and 40906038) and the National Basic Research Program of China (2007CB815903).

1 Beaufort L, de Garidel-Thoron T, Mix A C, et al. ENSO-like forcing on oceanic primary production during the late Pleistocene. Science, 2001, 293: 2440-2444

2 Beaufort L, de Garidel-Thoron T, Linsley B, et al. Biomass burning and oceanic primary production estimates in the Sulu Sea area over the last $380 \mathrm{kyr}$ and the East Asian monsoon dynamics. Mar Geol, 2003, 201: 53-65

3 Liu C L, Wang P X, Tian J, et al. Coccolith evidence for Quaternary nutricline variations in the Southern South China Sea. Mar Micropaleontol, 2008, 69: 42-51

4 Su X, Ma W L, Cheng Z B. Calcareous nannofossil biostratigraphy for Co-rich ferromanganese Crusts from central Pacific seamount (in Chinese). Earth Sci-J Chn Univ Geosci, 2004, 29: 141-147

5 Thierstein H R, Geitzenauer K, Molfino B, et al. Global synchroneity of late Quaternary coccolith datum levels: Validation by oxygen isotopes. Geology, 1977, 5: 400-404

6 Gartner S. Calcareous nannofossil biostartigraphy and revised zonation of the Pleistocene. Mar Micropaleontol, 1977, 2: 1-25

7 Matsuoka H, Okada H. Time-progressive morphometric changes of the genus Gephyrocapsa in the Quaternary sequence of the tropical Indian Ocean, Site 709. In: Duncan R A, Backman J, Peterson L C, et al., eds. Proceeding of the Ocean Drilling Program, Scientific Results, Volume 115. College Station, TX: Ocean Drilling Program, 1990. 255-270

8 Giraudeau J, Pujos A. Fonction de transfer basée surles nannofossiles calcaires du Pleistocéne des Caribes. Oceanol Acta, 1990, 13: 453469

9 Wei W. Calibration of upper Pliocene-lower Pleistocene nannofossil events with oxygen isotope stratigraphy. Paleoceanography, 1993, 8: 85-99 
10 Raffi I, Backman J, Rio D, et al. Plio-Pleistocene nannofossil biostratigraphy and calibration to oxygen isotope stratigraphies from Deep Sea Drilling Project Site 607 and Ocean Drilling Program Site 677. Paleoceanography, 1993, 8: 387-408

11 Weaver P P E, Thomson J. Calculating erosion by deep-sea turbidity currents during initiation and flow. Nature, 1993, 364: 136-138

12 Wells P, Okada H. Response of nannoplankton to major changes in sea-surface temperature and movements of hydrological fronts over Site DSDP 594 (south Chatham Rise, southeastern New Zealand), during the last $130 \mathrm{kyr}$. Mar Micropaleontol, 1997, 32: 341-363

13 Hine N, Weaver P P E. Quaternary. In: Bown P R, ed. Calcareous Nannofossil Biostratigraphy. London: Chapman and Hall, 1998. 266283

14 Bollmann J, Baumann K H, Thierstein H R. Global dominance of Gephyrocapsa coccoliths in the Pleistocene: Selective dissolution, evolution, or global environmental change? Paleoceanography, 1998, 13: $517-529$

15 Wei K-Y, Lee T Q. The Shipboard Scientific Party of IMAGES III/ MD106-IPHIS Cruise (Leg II). Nannofossil Biochronology of Tephra Layers in Core MD972143, Benham Rise, Western Philippine Sea. TAO, 1998, 9: 156-163

16 Zhou L P, Shackleton N J. Misleading positions of geomagnetic reversal boundaries in Eurasian loess and implications for correlation between continental and marine sedimentary sequences. Earth Planet Sc Lett, 1999, 168: 117-130

17 Glass B P, Pizzuto J E. Geographic-variation in Australasian microtektite concentrations-implications concerning the location and size of the source crater. J Geophys Res, 1994, 99: 19075-19081

18 Zhao Q H, Jian Z M, Li B H, et al. Microtektites in the middle Pleistocene deep-sea sediments of the South China Sea (in Chinese). Sci Chnia Ser D-Earth Sci, 1999, 29: 45-49

19 Lee Y M, Wei K Y. Australasian microtektite in the South China Sea and the West Phillippine Sea: Implications for age, size, and location of the impact crater. Meteorit Planet Sci, 2000, 35: 1151-1155

20 Glass B P, Wu J. Coesite and shocked quartz discovered in the Australasian and North America microtektite layers. Geology, 1993, 21: 435-438

21 Tauxe L, Herbert T, Shackleton N J, et al. Astronomical calibration of the Matuyama-Brunhes boundary: Consequences for magnetic remanence acquisition in marine carbonates and the Asian loess sequences. Earth Planet Sci Lett, 1996, 140: 133-146

22 Groetsch J, Wu G, Berger W H. Carbonate saturation cycles in the western equatorial Pacific. In: Einsele G, Ricken W, Seilacher A, eds. Cycles and Events in Stratigraphy. Heidelberg: Springer, 1991. 110-125

23 Crow E L, Davis F A, Maxfield M W. Statistics Manual. New York: Dover Publications Inc., 1960. 279

24 Dennison J M, Hay W W. Estimating the needed sampling area for subaquatic ecologic studies. Paleontology, 1967, 41: 706-708

25 Flores J-A, Marino M. Pleistocene calcareous nannofossil stratigraphy for ODP Leg 177 (Atlantic sector of the Southern Ocean). Mar Micropaleontol, 2002, 45: 191-224

26 Liu C L, Zhu Y H, Cheng X R. Calcareous nannofossil evidence for variations in Quaternary surface water paleoproductivity in the Southern South China Sea (in Chinese). Mar Geol Quater Res, 2001, 21: 61-66

27 Zhao J T, Li T G, Chang F M, et al. Evolution in upper water structure and paleoproductivity in the Northern margin of the Western Pacific Warm Pool and its forcing mechanism during the last $190 \mathrm{ka}$ BP evidence from nannofossil, foraminifera and their isotope composition (in Chinese). Oceanol Limnol Sin, 2008, 39: 305-311

28 Lisiecki L E. A Pliocene-Pleistocene stack of 57 globally distributed benthic $\delta^{18} \mathrm{O}$ records. Paleocenaography, 2005, 20: 1-17

29 Stuiver M, Reimer P J. Extended C-14 data-base and revised Calib
3.0 C-14 age calibration program. Radiocarbon, 1993, 35: 215-230

30 Young J, Westbroek P. Genotypic variation in the coccolithophorid species Emiliania huxleyi. Mar Micropaleontol, 1991, 18: 5-23

31 Flores J A, Gersonde R, Sierro F J, et al. Southern Ocean Pleistocene calcareous nannofossil events: Calibration with isotope and geomagnetic stratigraphies. Mar Micropaleontol, 2000, 40: 377-402

32 Flores J A, Gersonde R, Sierro F J. Pleistocene fluctuations in the Agulhas Current Retroflection based on the calcareous plankton record. Mar Micropaleontol, 1999, 37: 1-22

33 Raffi I. Revision of the early-middle Pleistocene calcareous nannofossil biochronology (1.75-0.85 Ma). Mar Micropaleontol, 2002, 45: $25-55$

34 Lourens L J, Hilgen F J, Raffi I, et al. Early Pleistocene chronology of the Vrica Section (Calabria, Italy). Paleoceanography, 1996, 11: $797-812$

35 Lourens L J, Hilgen F J, Raffi I. Base of Large Gephyrocapsae and astronomical calibration of early Pleistocene sapropels in ODP967 and 969: solving the chronology of the Vrica section. In: Robertson A H F, Emeis K C, Richter C, et al., eds. Proceeding of the Ocean Drilling Program, Scientific Results, Volume 160. College Station, TX: Ocean Drilling Program, 1998. 191-197

36 Rio D, Raffi I, Villa G. Pliocene-Pleistocene calcareous nannofossil distribution patterns in the Western Mediterranean. In: Kastens K A, Mascle J, eds. Proceeding of the Ocean Drilling Program, Scientific Results, Volume 107. College Station, TX: Ocean Drilling Program, 1990. 513-533

37 Ericson D B, Ewing M, Wollin G. Plio-Pleistocene boundary in the deep-sea sediments. Science, 1963, 139: 727-737

38 Channell J E T, Rio D, Sprovieri R, et al. Biomagnetostratigraphic correlations from Leg 107 in the Tyrrhenian Sea. In: Kastens K A, Mascle J, eds. Proceedings of the Ocean Drilling Program, Scientific Results, volume 107. College Station, TX: Ocean Drilling Program, 1990. 669-682

39 Chapman M R, Chepstow-Lusty A J. Late Pliocene climatic change and the global extinction of the Discoasters: an independent assessment using oxygen isotope records. Palaeogeogr Palaeoclimatol Palaeoecol, 1997, 134: 109-125

40 Fornaciari E. Calcareous nannofossils biostratigraphy of the California margin. In: Lyle M, Koizumi I, Richter C, eds. Proceedings of the Ocean Drilling Program, Scientific Results, volume 167. College Station, TX: Ocean Drilling Program, 2000. 3-40

41 Wise S W. Calcareous nannofossils from cores recovered during Leg 18, Deep Sea Drilling Project: Biostratigraphy and observation of diagenesis. In: Kulm L D, von Huene R, eds. Initial Reports of DSDP, volume 18. Washington: US Govt. Printing Office, 1973. 569-615

42 Burns C A. Timing between a large impact and a geomagnetic reversal and the depth of NRM acquisition in deep-sea sediments. In: Lowes F J, Collinson D W, Parry J H, et al., eds. Geomagnetism and Paleomagnetism. Dordrecht: Kluwer Academic Publishers, 1989. 253-261

43 Hou Y M, Potts R, Yuan B Y, et al. Mid-Pleistocene Acheulean-like stone technology of the Bose Basin, South China. Science, 2000, 287: $1622-1625$

44 Kunz J, Bollinger K, Jessberger E K, et al. Ages of Australasian Tektites. Abstracts of the Lunar and Planetary Science Conference XXVI. Houston, TX: Lunar and Planetary Institute, 1995. 809-810

45 Schneider D A, Kent D V, Mello G A. A detailed chronology of the Australasian impact event, the Brunhes-Matuyama geomagnetic polarity reversal, and global climate change. Earth Planet Sci Lett, 1992 111: 395-405

46 Li X, Zhao Q H, Huang B Q, et al. High-resolution age estimation of the mid-Pleistocene impact event (in Chinese). Mar Geol Quat Geol, 2004, 24: 73-77

Open Access This article is distributed under the terms of the Creative Commons Attribution License which permits any use, distribution, and reproduction in any medium, provided the original author(s) and source are credited. 